\title{
PUNDEN SEBAGAI PUSAT KEHIDUPAN SOSIAL DAN BUDAYA MASYARAKAT DESA KLEPEK KABUPATEK KEDIRI
}

\author{
Muhammad Andi Finaldi Nurtantyo
}

176060500111004

afinaldi@ymail.com

0857338956600

\begin{abstract}
Abstrak
Kata kunci :

Desa Klepek memiliki kearifan lokal dalam aspek kehidupan sosial dan budaya. Aspek aspek sosial, aspek budaya, punden, kearifan sosial budaya yang dimiliki sangat menarik untuk dibahas dalam penelitian ini. Aspek sosial budaya yang terdapat disana berhubungan dengan satu tempat sakral yang dijadikan pusat yaitu punden. Kepercayaan masyarakat desa Klepek menganggap punden sebagai titik pusat kehidupan sosial mereka. Hal ini terlihat adanya kegiatan tradisi masyarakat yang tidak terlepas dari keberadaan punden tersebut. Kegiatan tradisi yang terdapat disana yaitu nyadranan, barik'an dan tradisi sebelum hajatan. Fokus pada penelitian ini yaitu aspek kehidupan sosial dan budaya yang terdapat di desa Klepek. Metode penelitian ini menggunakan metode kualitatif yang didalamnya terdapat tentang data deskriptif tertulis ataupun lisan dari sumber objek. Dengan hubungan antara aspek kehidupan sosial budaya dengan punden maka dapat menghasilkan data indentifikasi berupa keragaman aspek sosial budaya.
\end{abstract}




\section{Punden sebagai Pusat Kehidupan Sosial dan Budaya Masyarakat Desa Klepek Kabupatek Kediri \\ Muhammad Andi Finaldi Nurtantyo}

\section{Pendahuluan}

Klepek merupakan salah satu desa yang ada di kabupaten Kediri yang bertepatan di kecamatan Kunjang. Secara geografis desa Klepek merupakan permukiman desa agraris sehingga desa tersebut terlihat indah dan asri. Dengan keberadaannya sebagai permukiman desa agraris penduduknya memanfaatkan sebagai lahan mata pencaharian untuk bertani dan bercocok tanam. Penggunaan lahan desa Klepek sebagian besar didominasi oleh lahan pertanian dan permukiman warga.

Disamping itu desa Klepek kaya akan kearifan sosial budaya yang menarik untuk dibahas. Sosial budaya yang tedapat disana seperti kegiatan tradisi yang rutin diadakan pada waktu tertentu. Setiap tradisi yang diadakan desa Klepek selalu melibatkan dengan suatu tempat yang disakralkan, yaitu sebuah punden. Kegiatan tradisi yang dilakukan masyarakat Desa Klepek yang melibatkan punden tersebut mulai dari tradisi kegiatan tradisi sebelum ada hajatan warga desa, barikan, dan nyadranan.

Dengan adanya punden yang mewadahi upacara dan kegiatan tradisi sehingga dapat menjadi faktor pembentukan konsep ruang. Dengan terbentuknya konsep ruang dapat menciptakan interaksi sosial masyarakat dalam hal berkegiatan, berperilaku dan berkomunikasi memberikan identitas lokal yang merupakan wujud dari segi arsitektur. Perwujudan dari segi arsitektur yang berhubungan dengan aktivitas manusia dalam hal pergerakannya pada ruang fisik satu dengan ruang lainnya, sehingga terciptanya tekanan antar ruang, baik ruang dalam dan ruang luar (Slamet, 2015).

Aspek sosial budaya pada masyarakat desa Klepek di sini akan menjadi fokus pembahasan penilitian ini. Sehingga dapat mengetahui aspek kehidupan sosial dan kehidupan budaya masyarakat desa Klepek. Disamping hal itu pula dapat diketahui dalam tradisi budaya masyarakat desa Klepek yang sangat memiliki ikatan yang kuat dengan suatu tempat yang disakralkan.

\section{Tujuan}

a. Mengidentifikasi aspek fisik dengan lingkup secara makro dan mikro.

b. Mengidentifikasi dari aspek non fisik yang berhubungan dengan sosial budaya masyarakat desa Klepek.

\section{Manfaat}

a. Bagi peneliti, diharapkan menambah wawasan dan pengetahuan mengenai sosial budaya yang terikat dengan ruang.

b. Bagi kalangan akademik, diharapkan dapat menjadi bahan penelitian selanjutnya yang lebih spesifik.

c. Bagi pemerintah kota dan kabupaten, diharapkan menjadi bahan pertimbangan dalam menetapkan suatu kebijakan tentang pelestarian tradisi budaya.

\section{Bahan dan Metode Penelitian}

\section{Bahan Peneitian}

\section{Sosial}

Manusia pada dasarnya merupakan makhluk sosial yang memiliki naluri untuk bertahan hidup dengan orang lain. Naluri itu dapat disebut juga dengan gregariousness sehingga manusia juga disebut 
sebagai social animal (hewan sosial). Sejak kelahiran manusia sudah memiliki hasrat atau keinginan pokok untuk menjadi satu dengan manusia lain disekelilingnya (masyarakat) dan suasana alam sekelilingnya. Maka terjadilah interaksi sosial didalamnya (Soekanto, 2015).

Pembahasan mengenai sosial secara tidak langsung juga membahas mengenai interaksi sosial. Dimana interaksi sosial merupakan bentuk umum dari proses sosial juga bagian dari aspek sosial. Oleh karena itu interaksi sosial merupakan syarat utama untuk terjadi aktivitas-aktivitas berhubungan dengan aspek sosial. Menurut Gillin, Cultural Sociology: a revision of an introduction to sociology, 1954:hlm. 489 interaksi sosial adalah hubungan-hubungan sosial antara individu dengan individu, antara kelompok dengan kelompok, maupun antara individu dengan kelompok (Gillin, 1954).

\section{Budaya dan Kebudayaan}

Budaya merupakan pemaknaan bagi serangkaian kegiatan, biasanya ditentukan oleh aturan yang sudah diterima sejak awal dan bersifat ritual atau simbolik, yang bertujuan menanamkan nilai dan norma perilaku melalui kebiasaan, yang dengan sendirinya membentuk kesinambungan dengan masa lalu. Bahkan hal ini akan membangun kesinambungan dengan sejarah masa lalu yang sesuai(Beng, 1998).

Terdapat perbedaan mengenai budaya dan kebudayaan. Budaya dapat juga dimaksud dengan daya dan budi. sarana berupa karya, rasa, dan cipta dari masyarakat untuk mempertahankan karya penciptaannya menyangkut kepercayaan, kesenian, kebiasaan, dan adat istiadat yang sudah disesuaikan dengan pengalaman lingkungan sekitarnya (Koentjaraningrat, 2015).

Sedangkan untuk kebudayaan juga dapat mempengaruhi pengetahuan yang meliputi ide dan gagasan yang ada dalam pemikiran masing-masing individu masyarakat yang bersifat abstrak. Dalam wujud dari kebudayaan yang diciptakan oleh manusia seperti pola perilaku, bahasa keseharian, organisasi sosial, seni, agama termasuk juga dalam kegiatan tradisi suatu masyarakat (Koentjaraningrat, 2015).

Dalam kebudayaan terdapat pembahasan mengenai wujud kebudayaan yang mencakup didalamnya terdapat unsur-unsur pembentuknya. Menurut Koentjaraningrat dalam buku Pengantar Ilmu Antropologi,2015:hlm.165 unsur-unsur kebudayaan meliputi 7 hal, yaitu: (1) bahasa, (2) sistem pengetahuan, (3) organisasi sosial, (4) sistem peralatan hidup dan teknologi, (5) sistem mata pencaharian, (6) sistem religi, (7) kesenian. Dari unsur-unsur kebudayaan tersebut dapat ditemukan pada semua bangsa-bangsa di dunia karena merupakan unsur kebudayaan yang bersifat universal (Koentjaraningrat, 2015).

Menurut J.J Honigman dalam buku The World of Man,1959:hlm. 11-12 kebudayaan memiliki 3 wujud, yaitu (1) ide, (2) aktivitas, (3) artefak (Honigmann, 1954). Dari 3 wujud tersebut dapat dijelaskan mengenai gejala kebudayaan, yaitu:

a. Wujud kebudayaan identik dengan kompleksitas yang terbentuk dari ide, gagasan, nilai, norma dan peraturan.

b. Wujud kebudayaan identik dengan suatu kompleks aktivitas serta tindakan yang berpola dari individu didalam masyarakat.

c. Wujud kebudayaan artefak sebagai hasil dari karya manusia berupa benda-benda peninggalan yang tetap terjaga. 


\section{Punden sebagai Pusat Kehidupan Sosial dan Budaya Masyarakat Desa Klepek Kabupatek Kediri \\ Muhammad Andi Finaldi Nurtantyo}

\section{Metode}

Berdasarkan penelitian ini yang membahas mengenai sosial budaya masyarakat desa Klepek yang memiliki hubungan dengan tempat yang disakralkan. Dalam hal ini tidak hanya membahas tentang aspek budaya dan sosialnya saja tetapi juga tentang aspek arsitekturnya. Penelitian ini menggunakan metode kualitatif yang memuat tentang data deskriptif tertulis ataupun lisan dari sumber dan objek yang diamati.

Data diperoleh dari observasi pada objek dan wawancara secara lisan kepada narasumber. Perolehan data dari observasi dan wawancara dilakukan untuk memperoleh keseluruhan data mengenai aspek sosial budaya masyarakat yang berhubungan dengan punden.

Langkah selanjutnya dilakukan penyusunan dengan cara sistematis untuk melakukan identifikasi secara deskriptif. identifikasi dilakukan dengan tujuan untuk memperoleh hasil dari bagaimana hubungan dari aspek sosial budaya dari masyarakat dalam melibatkan punden tersebut.

\section{Pembahasan}

\section{Gambaran Umum Lokasi}

\section{Lingkungan fisik alam (Makro)}

Kabupaten Kediri berada pada posisi geografi terletak antara $111^{\circ} 47^{\prime} 05^{\prime \prime}$ sampai dengan $112^{\circ}$ 18'20" Bujur Timur dan $7^{\circ} 36^{\prime} 12^{\prime \prime}$ sampai dengan $8^{\circ} 0^{\prime} 32$ Lintang Selatan. Kondisi topografi terdiri dari dataran rendah dan pegunungan yang dilalui aliran sungai Brantas yang membelah dari selatan ke utara. Suhu udara berkisar antara $23^{\circ} \mathrm{C}$ sampai dengan $31^{\circ} \mathrm{C}$ dengan tingkat curah hujan rata-rata sekitar $1652 \mathrm{~mm}$ per hari. Wilayah Kabupaten kediri diapit oleh dua gunung yang berbeda sifatnya, yaitu Gunung Kelud di sebelah Timur yang bersifat Vulkanik dan Gunung Wilis disebelah barat yang bersifat non vulkanik, sedangkan tepat di bagian tengah wilyah Kabupaten Kediri melintas sungai Brantas yang membelah Wilayah Kabupaten Kediri. Adapun wilayah admisnistratif Kabupaten Kediri diapit oleh 5 Kabupaten, yakni:

- Sebelah Barat : Tulungagung dan Nganjuk

- Sebelah Utara : Nganjuk dan Jombang

- Sebelah Timur : Jombang dan Malang

- Sebelah Selatan : Blitar dan Tulungagung

\section{Karakteristik fisik elemen pembentuk kawasan desa klepek}

Elemen pembentuk kawasan didasari dengan penggunaan teori tentang proses dan bentuk dari terbentuknya suatu permukiman yang telah dikemukakan oleh (Carmona, 2003). Macam-macam elemen yang dibentuk mengenai morfologi ruang, yaitu:

a. Land Use (Penggunaan Lahan)

Kabupaten Kediri khususnya di desa Klepek merupakan kawasan agraris yang masih banyak lahan perkebunan dan persawahan yang luas. Sehingga dalam penggunan lahan yang terbentuk pada desa Klepek terdiri dari permukiman masyarakat yang masih didominasi oleh area perkebunan 
dan persawahan masyarakat. Dengan lahan permukiman yang khas agraris maka masyarakat setempat sebagian besar berlatar belakang sebagai petani dan juga peternak.

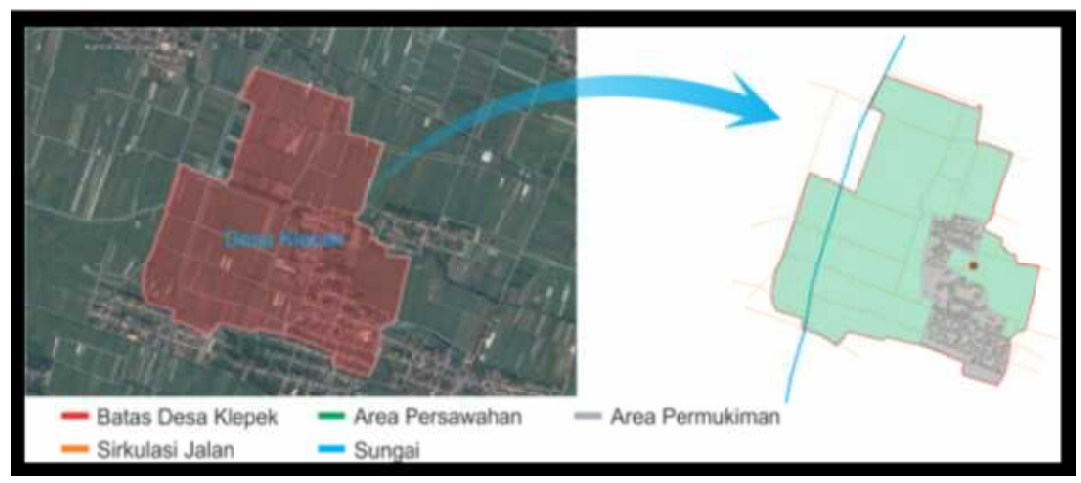

Gambar 1. Desa Klepek

Kecamatan Kunjang Kabupaten Kediri-Jawa Timur

(Sumber : Dokumentasi Pribadi, 2017)

Penggunaan tata guna lahan desa Klepek memiliki 2 fasilitas bangunan, yaitu fasilitas khusus dan fasilitas umum. Fasilitas bangunan khusus yang berfungsi sebagai hunian yaitu perumahan, untuk fasilitas umum masyarakat memiliki fungsi sebagai pendidikan dan fungsi peribadatan. Untuk fasilitas yang berfungsi sebagai pendidikan seperti sekolah dan ruang terbuka, sedangkan yang berfungsi sebagai peribadatan seperti masjid dan gereja.

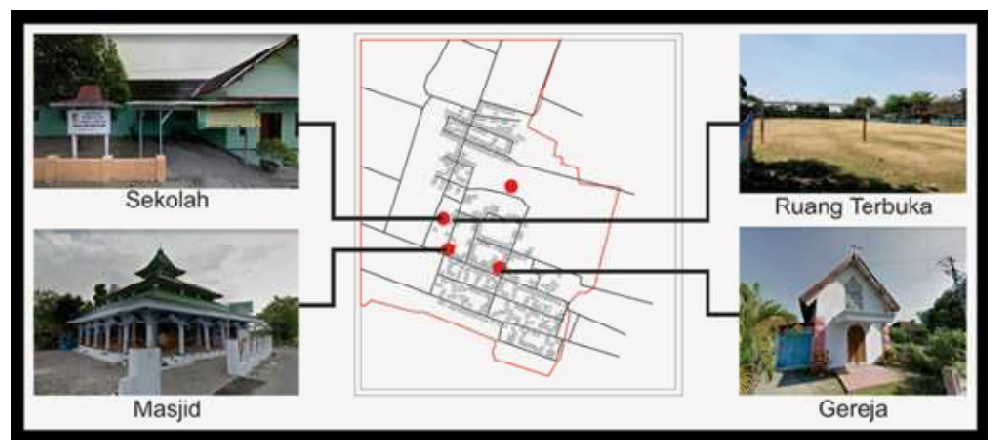

Gambar 2. Fasilitas umum desa Klepek (Sumber: Dokumentasi Pribadi, 2017)

b Building Structures (Tipe dan Massa Bangunan)

Dengan latar belakang sebagai petani dan peternak dapat berpengaruh pada perkembangan bidang arsitektur setempat. Bidang arsitektur yang terpengaruhi dapat terlihat pada setiap fisik dan ruang pada setiap rumah masyarakat. Tipe bangunan yang ada di desa Klepek berbentuk dan menggunakan material bangunan rumah sederhana. Hal ini dapat dilihat dari wujud fasad dan struktur konstruksi bangunannya sehingga dapat menjadi ciri khas hidup dirumah pedesaan. Selain itu juga setiap rumah di desa Klepek mayoritas memiliki ruang teras yang luas mencerminkan profesi 


\section{Punden sebagai Pusat Kehidupan Sosial dan Budaya Masyarakat Desa Klepek Kabupatek Kediri \\ Muhammad Andi Finaldi Nurtantyo}

masyarakat desa Klepek yaitu bertani. Ruang teras tersebut difungsikan sebagai tempat untuk menjemur hasil dari panen masyarakat.

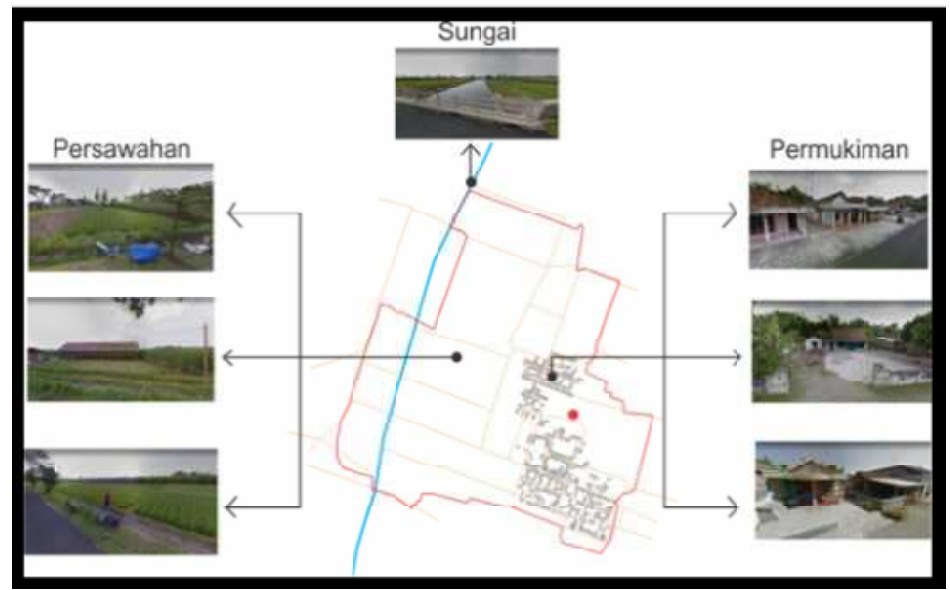

Gambar 3. Zona Desa Klepek

(Sumber: Dokumentasi Pribadi, 2017)

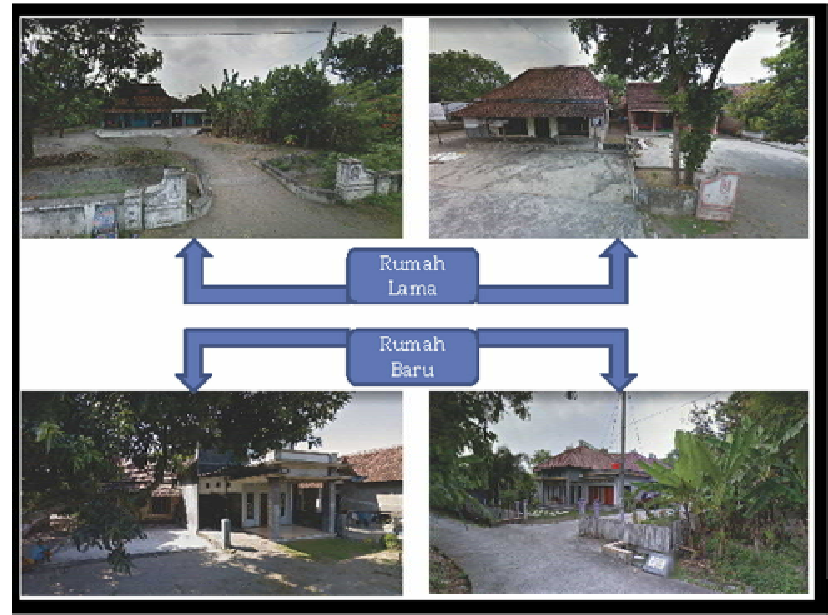

Gambar 4. Perbandingan rumah tradisional dan rumah modern desa Klepek

(Sumber: Dokumentasi Pribadi, 2017)

\section{c. Plot Pattern (Pola Kapling)}

Plot pattern memiliki maksud bahwa dalam perkembangan kawasan khususnya desa Klepek dapat mengalami perubahan bentuk. Perubahan bentuk dapat melalui proses penambahan dan pengurangan baik dari segi pembagian, pemisahan, perpindahan penghapusan dan pertukaran. Pola penataan massa bangunan pada desa Klepek berdasar pada system kekerabatan. Selain itu juga orientasi pada penataan bangunan desa Klepek mengikuti jalur jalan. Hal ini dapat dilihat dari sepanjang jalan primer maupun sekunder orientasi bangunan menghadap ke jalan. 


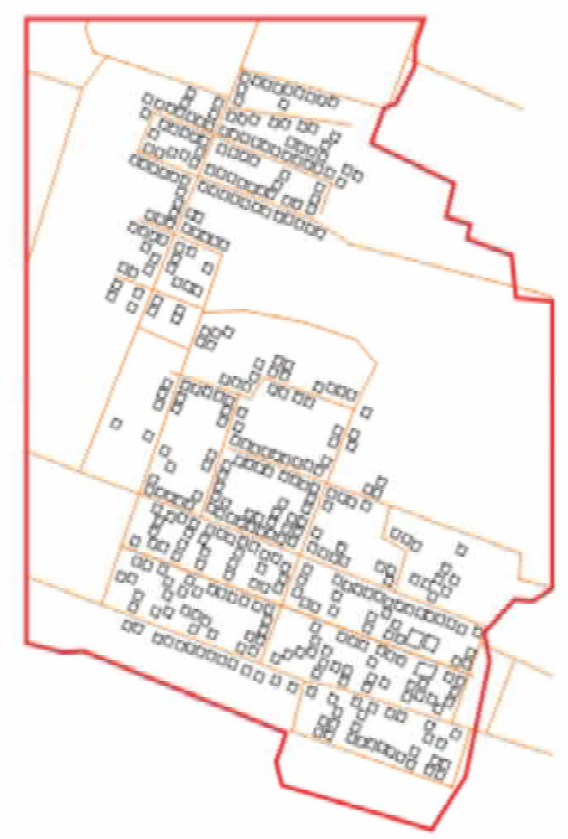

Gambar 5. Orientasi bangunan menghadap ke jalan (Sumber : Dokumentasi Pribadi, 2017)

d. Street Pattern (Pola Jalan atau Sirkulasi)

Pola jalan pada desa Klepek terbangun secara natural atau tidak terencana. Setiap terdapat pertumbuhan penduduk disatu titik dapat terbentuk jaringan jalan secara natural. Hal tersebut juga merupakan kesepakatan pemerintah dengan masyarakat setempat. Pola sirkulasi desa Klepek dibagi menjadi 3 yaitu Jalan Primer, jalan sekunder, dan jalan koridor. Untuk akses jalan primer dan sekunder yang difungsikan sebagai dua jalur kendaraan bermotor terbentuk dengan material aspal. Sedangan pada jalan koridor terbentuk dengan kondisi perkerasan alami yang hanya menghubungkan sirkulasi antar bangunan rumah memiliki kekerabatan yang dekat.

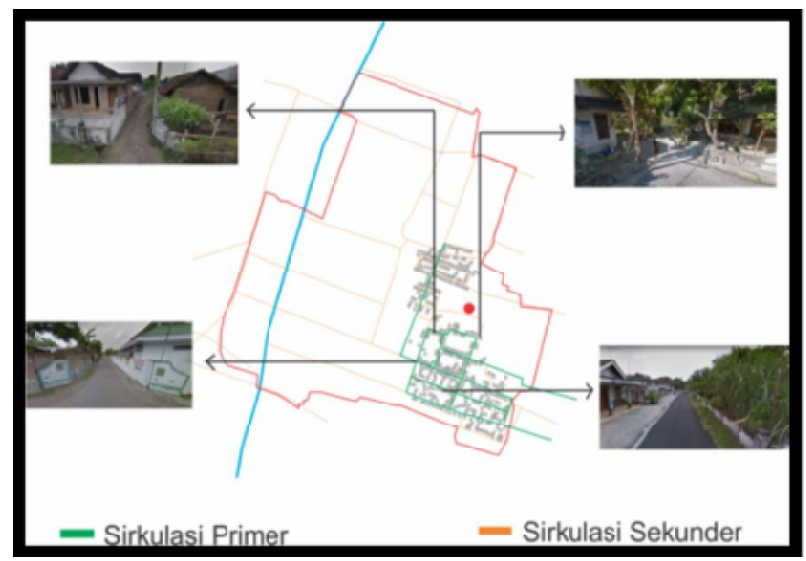

Gambar 6. Pola Sirkulasi Desa Klepek

(Sumber : Dokumentasi Pribadi, 2017) 


\section{Punden sebagai Pusat Kehidupan Sosial dan Budaya Masyarakat Desa Klepek Kabupatek Kediri \\ Muhammad Andi Finaldi Nurtantyo}

\section{Lingkup fisik objek (mikro)}

Lokasi tepatnya punden terletak pada tengah-tengah pola permukiman warga. Lingkungan sekitar punden tersebut dikelilingi oleh ruang terbuka berupa persawahan dan pekarangan. Wujud fisik punden dikelilingi pembatas pagar yang sengaja dibuat oleh swadaya masyarakat setempat. Di area punden terdapat pula sebuah pendopo yang di bangun dengan fungsi sebagai pernaungan untuk peziarah dan ruangan jika terdapat acara tertentu diadakan yang melibatkan punden. Didalam area punden terdapat pohon yang tumbuh secara natural mengelilinginya. Dalam area punden terdapat pagar juga yang mengelilingi makam dari mbah Komari Hirojoyo. Hal itu merupakan tempat yang paling disakralkan oleh masyarakat setempat. Tempat sakral tersebut ditandai dengan sebuah makam yang dinaungi oleh 4 pohon buah jambu kelampok yang sudah berusia lebih dari seratus tahun.

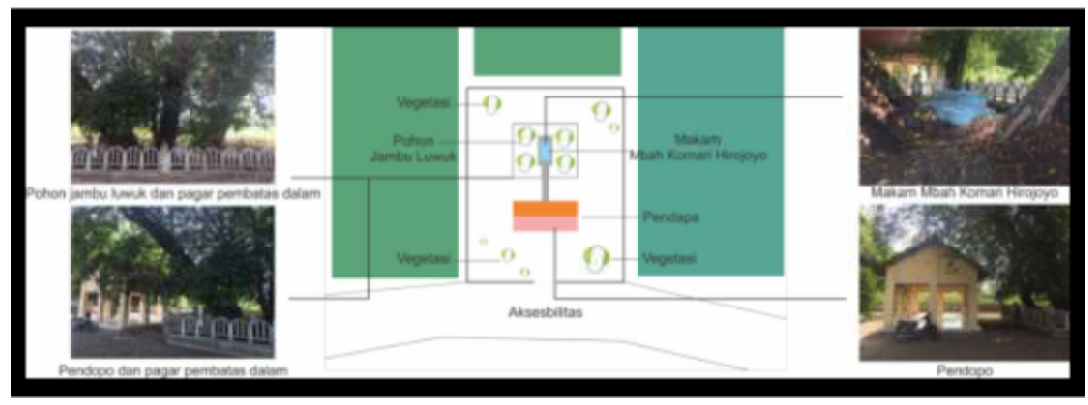

Gambar 7. Wujud Fisik Punden

(Sumber : Dokumentasi Pribadi, 2017)

\section{Aspek Kehidupan Sosial}

Apek sosial budaya dalam pembahasannya berdasarkan pada unsur kebudayaan menurut (Koentjaraningrat, 2015), yaitu:

\section{Bahasa}

Bahasa yang digunakan masyarakat dalam kehidupan sehari-hari adalah Bahasa Jawa. Dimana tatanan bahasa Jawa ngoko alus yang lebih sering digunakan daripada karma inggil. Komunikasi antara muda dengan tua atau tua dengan muda memiliki kesamaan bahasa.

\section{Sistem pengetahuan}

Masyarakat desa Klepek yang hidup dari bertani akan memiliki sistem kalender pertanian tradisional. Melalui sistem ini para petani akan mengetahui kapan saat mulai mengolah tanah, saat menanam, dan saat memanen hasil pertaniannya karena semua aktivitas pertaniannya didasarkan pada siklus peristiwa alam. 


\section{Organisasi sosial dan religi}

Sosial budaya masyarakat di Desa Klepek masih sangat kental dengan budaya ritual keagamaan yang selalu dilakukan pada hari dan tempat. Terdapat 2 pemeluk agama di desa Klepek yaitu agama Islam dan agama Kristen. Mayoritas besar masyarakat desa Klepek menganut agama Islam, meskipun dalam pelaksanaan ritual-ritual tertentu masih bercampur dengan Budaya Kejawen. Kondisi masyarakat desa Klepek terlihat guyub dan rasa gotong royong masih kental antar tetangga. (Koentjaraningrat, 2015), menyatakan bahwa solidaritas adalah suatu bentuk kerjasama pada masyarakat yang meliputi aktivitas gotong royong, tolong menolong dan musyawarah. Selain rasa kepatuhan yang didasarkan kepada perasaan moral, masyarakat juga mengenal seperangkat nilai yang intinya memupuk rasa solidaritas atau disebut nilai yang mempersatukan (assosiatif) yang mempunyai butir-butir positif yaitu persaudaraan, kekeluargaan, kerukunan dan kegotong-royongan.

\section{Sistem peralatan hidup dan tekonologi}

Teknologi pertanian dari segi keberlanjutan hidup masyarakat desa Klepek. Sistem teknologi pertanian sudah mengenal mesin dalam perawatan lahan pertaniannya.

\section{Sistem mata pencaharian}

Mata pencaharian mayoritas penduduk desa Klepek adalah petani dan peternak. Terlihat dari lahan persawahan yang masih sangat luas dan subur ditanami padi. Sedangkan ada beberapa lahan yang digunakan sebagai lahan peternakan. Hasil dari pertanian dan peternakan ini digunakan masyarakat desa untuk memenuhi kebutuhan hidup sehari-hari. Ada juga lahan pertanian warga yang disewakan sehingga warga memiliki pekerjaan lain.

\section{Kesenian}

Kesenian yang terdapat di desa Klepek berupa wayangan dan ludrukan. Hal ini karena berhubungan dengan kegiatan rutin tahunan yang dilakukan masyarakat desa Klepek.

\section{Aspek Tradisi Budaya Tradisi masyarakat sebelum hajatan}

Dalam tradisi masyarakat desa Klepek yang akan memiliki atau mengadakan hajatan. Baik hajatan tersebut merupakan hajatan pernikahan maupun sunatan harus melakukan suatu tradisi. Dalam tradisi ini masyarakat harus melakukan ziarah dan pamit meminta izin kepada danyang atau makam dari mbah Komari Hirojoyo. Tradisi tersebut dilakukan dengan dasar niatan meminta izin dan bertujuan agar setiap kegiatan hajatan berjalan dengan lancar. Dalam pelaksanaan tradisi tersebut dilakukan dengan cara sangat sederhana. Kegiatan tradisi tersebut tidak menuntut masyarakat untuk bersusah payah dalam melakukannya. Masyarakat desa Klepek hanya diwajibkan untuk membawa ambeng yang berupa nasi tumpeng berisi ayam panggang utuh dengan urap-urap sebagai pelengkap. 


\section{Punden sebagai Pusat Kehidupan Sosial dan Budaya Masyarakat Desa Klepek Kabupatek Kediri \\ Muhammad Andi Finaldi Nurtantyo}

\section{Tradisi barik'an}

Terdapat tradisi berskala kecil yang merupakan sedekah dusun dari dusun Banengan. Dusun Banengan sendiri merupakan salah satu dusun yang terdapat di desa Klepek. Tradisi tersebut dapat juga disebut sebagai nyadranan tetapi hanya lingkup dusun. Tradisi bari'an diikuti oleh seluruh masyarakat desa Klepek. Bagi masyarakat dusun Banengan, tradisi bari'an didasari dengan niatan dan tujuan untuk mensyukuri hasil panen. Sedangkan bagi masyarakat desa Klepek yang diluar dusun Banengan merupakan niatan untuk membalas (ngimbangi) acara nyadranan dusun Banengan.

Waktu pelaksanaan tradisi bari'an itu sendiri tepatnya pada saat setelah panen pari (padi) musim rending. Dalam rangkaian acaranya hanya dilakukan sehari saja yang melibatkan punden sebagai pusat tradisi. Tradisi dimulai pada pagi hari yang diawali dengan acara kondangan di punden. Kondangan tersebut diikuti oleh seluruh masyarakat desa Klepek dengan membawa ambeng berupa tumpeng berisi ayam panggang. Setelah kegiatan acara kondangan, masyarakat desa Klepek melakukan ater-ater tumpeng keculai masyarakat dusun Banengan yang melakukan makan bersama. Makan bersama yang dilakukan masyarakat Banengan dilakukan di pinggiran sepanjang jalan yang sekelilingnya merupakan area persawahan.

\section{Tradisi nyadranan}

Dalam pelaksanaan upacara nyadranan desa Klepek selalu diikuti semua warga desa tanpa terkecuali. Upacara nyadranan desa Klepek tidak mengenal status, jabatan, maupun agama. Sehingga dalam pelaksanaan nyadranan berarti pemerataan status masyarakat adalah sama. Upacara nyadranan desa Klepek juga merupakan momen yang paling baik dalam berkumpulnya masyarakat. Karena upacara nyadranan memiliki prinsip bahwa jika sudah memperingati masyarakat harus fokus dan semua kegiatan diliburkan. Pelaksanaan nyadranan itu sendiri berbeda antara nyadranan pada saat agama Islam belum berpengaruh dengan nyadranan pada saat agama Islam sudah berpengaruh.

\section{Upacara nyadranan pada saat agama Islam belum berpengaruh}

Menurut mbah Joyoboyo, pada zaman dahulu nyadranan hanya dilakukan sesederhana mungkin. Zaman dahulu serangkaian acara nyadranan berbeda dengan yang sekarang terletak pada niat, durasi waktu, dan ambeng (peralatan) yang dibawa pada saat nyadranan. Niat nyadranan pada zaman dahulu hanya sebatas membersihkan desa dan memperingati hari ulang tahun desa saja. Hal tersebut hanya dilakukan pada hari Jumat Pahing bulan Suro dan masyarakat hanya membawa ambeng berupa bunga dan winayah (dupa) saja.

\section{Upacara nyadranan pada saat agama Islam berpengaruh}

Nyadranan pada saat ini telah berkembang banyak setelah agama Islam berpengaruh. Perbedaan terletak pada saat ini nyadranan dilaksanakan dengan niatan yang lebih dalam lagi. Kegiatan nyadranan diniatkan masyarakat sebagai perwujudan rasa syukur sebesar-besarnya kepada yang Tuhan Maha Kuasa. Wujud syukur dilakukan melalui perantara upacara nyadranan di lokasi punden dari danyang, karena menurut warga sekitar menganggap bahwa mbah Komari Hirojoyo merupakan wali dari Tuhan. 
Kemudian perbedaan pada ambeng yang dibawa masyarakat saat ini. Setelah agama Islam berpengaruh ambeng yang dibawa hanya makanan yang sudah ditentukan dan hanya bunga ziarah saja. Sehingga untuk ambeng berupa winayah tidak diperbolehkan lagi.

Perbedaan selanjutnya pada pelaksanaan upacara nyadranan di desa Klepek dibagi menjadi tiga serangkaian waktu yaitu malem Jumat (Pra-nyadran), malem sabtu (Jumat pahing, nyadranan), malem minggu (pasca-nyadranan).

Acara pra-nyadranan yang dilakukan pada hari kamis malam jumat dilaksanakan terlebih dahulu yaitu pembersihan punden (makam) oleh pamong-pamong desa Klepek. Pembersihan punden dilakukan tidak boleh sembarangan, karena pembersihan punden sendiri harus dilakukan oleh pamong-pamong desa saja. Setelah pembersihan makam, memasuki waktu sore hari masyarakat setempat khususnya untu laki-laki melakukan ziarah kubur atau tabur bunga dengan membawa ambeng. Barang bawaan ambeng yang berupa bunga yang berfungsi untuk ditaburkan di makam.

Selepas acara ziarah kubur dilaksanakan acara selanjutnya setelah maghrib yaitu tahlil bersama dilaksanakan di punden yang diikuti seluruh masyarakat laki-laki desa Klepek. Acara tahlil diikuti pula oleh pamong-pamong yang sekaligus membawa ambeng lagi. Waktu berakhirnya tahlil tersebut pada saat akan memasuki waktu Isya'. Setelah tahlil dilaksanakan, masyarakat desa Klepek melanjutkan acara begadang bersama sampai terbitnya matahari yang dilaksanakan di punden tersebut.

Menurut kepercayaan masyarakat setempat, mbah Komari Hirojoyo memiliki peliharaan ghaib (ingon-ingon) berupa macan putih. Macan putih tersebut muncul pada saat setiap malam Jumat menjelang acara utama. Munculnya macan putih dengan tujuan untuk melindungi masyarakat dari bahaya yang tidak diinginkan. Tidak semua masyarakat yang dapat melihat wujud macan putih tersebut, hanya orang tertentu yang dapat melihatnya. Selama ini yang dapat melihat wujud macan putih hanyalah kepala desa yang menjaga kentongan yang merupakan tempat berhentinya macan putih setelah mengelilingi desa.

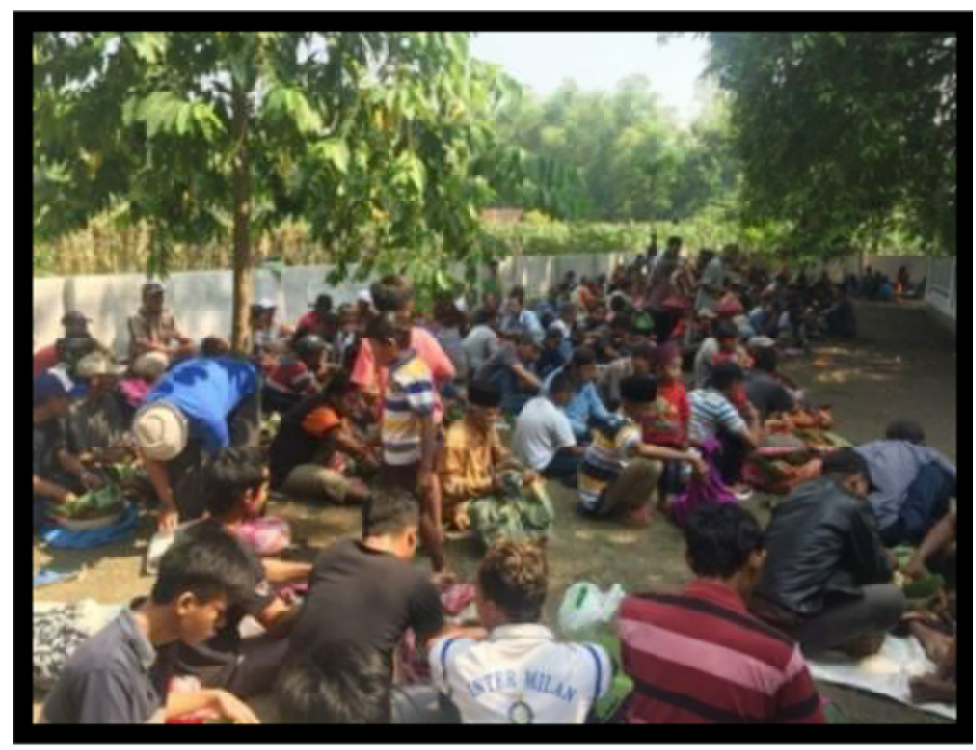

Gambar 8. acara nyadranan desa Klepek

(Sumber: Dokumentasi Pribadi, 2017) 


\section{Punden sebagai Pusat Kehidupan Sosial dan Budaya Masyarakat Desa Klepek Kabupatek Kediri \\ Muhammad Andi Finaldi Nurtantyo}

Untuk keesokan harinya tepat pada hari Jumat Pahing dilaksanakan terlebih dahulu ziarah kubur kembali bagi masyarakat yang belum melaksanakannya. Ziarah pagi hari dilaksanakan sampai menjelang siang sekitar pukul 09.00 wib. Kemudian dilanjutkan dengan acara utama yaitu kondangan masyarakat desa Klepek menyebutnya. Dengan antusias masyarakat yang berbondong-bondong membawa masingmasing tumpeng (makanan yang wajib dibawa). Acara kondangan dilaksanakan oleh semua masyarakat desa Klepek dengan membawa tumpeng yang berisi nasi putih, urap-urap, dan ayam utuh yang dipanggang.

Selepas acara utama pada hari Jumat Pahing yang di akhiri -ater-ater kepada saudara dilaksanakan acara hiburan. Acara hiburan merupakan puncak dari nyadranan yang berupa acara ludrukan atau wayangan yang dilaksanakan dimana letak dari kentongan yang disinggahi macan putih.

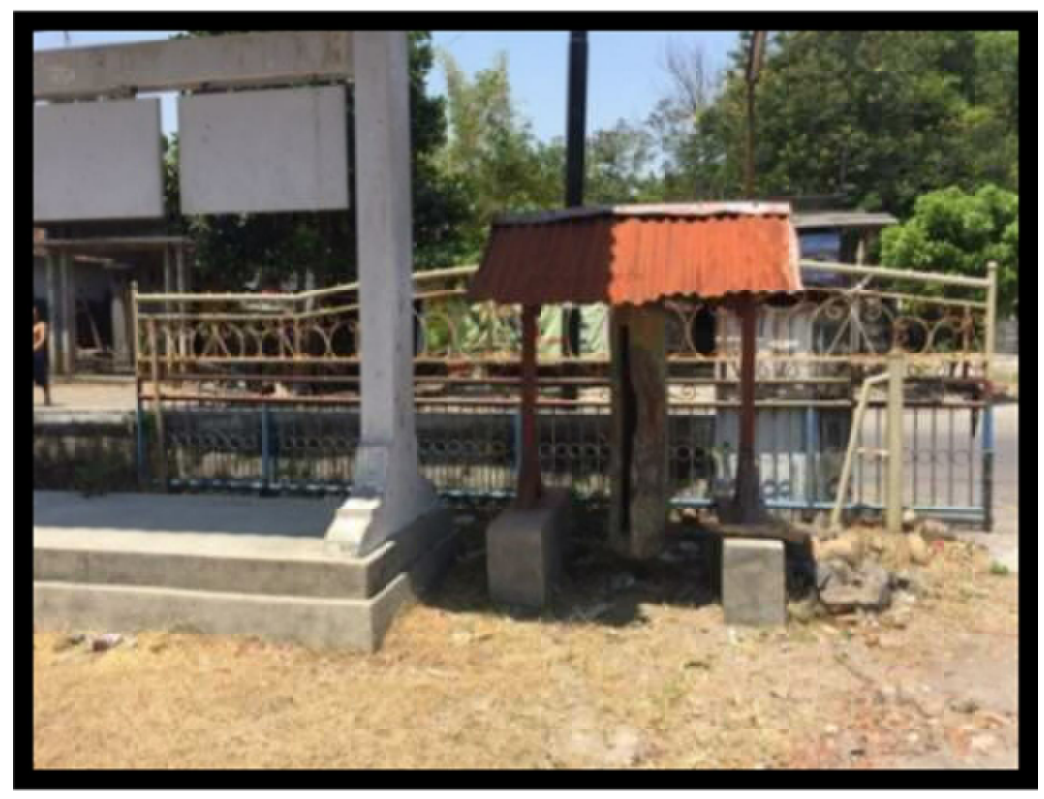

Gambar 9. Letak kentongan

(Sumber: Dokumentasi Pribadi, 2017)

Menurut masyarakat desa Klepek, sudah dari zaman dahulu acara penutupan selalu mengadakan ludrukan dan wayangan. Ada pantangan tersendiri jika mengadakan acara penutupan dengan acara yang lain. Hal ini dikarenakan dahulu pernah mengadakan acara penutupan dengan acara jaranan yang mengakibatkan bencana atau kejadian yang tidak diinginkan. Bencana tersebut melanda desa Klepek yaitu datangnya angin puting beliung. Semenjak kejadian tersebut tidak pernah mengadakan acara penutupan dengan jaranan. Menurut kepercayaan masyarakat acara ludrukan dan wayangan merupakan acara yang sangat sakral dan disukai oleh mbah Komari Hirojoyo.

\section{Kesimpulan}

Punden sebagai pusat ruang sosial budaya masyarakat menjadi wadah kegiatan dari hasil karya manusia yang memiliki ikatan rasa, kesan, cipta antara ruang dengan masyarakat yang sudah mengakar 
turun temurun. Ikatan ruang dengan masyarakat yang sudah berubah kepercayaan yang dilandaskan dengan hukum Islam. Dengan tercipta dan terbentuknya ikatan antara ruang dan masyarakat maka hal itu dapat dikatakan sebagai kehadiran segi arsitekturnya.

Keberadaan aspek kehidupan sosial masyarakat dengan aspek tradisi budaya saling memiliki hubungan timbal balik. Sebagaimana kehidupan sosial masyarakat desa Klepek yang mempengaruhi tradisi budaya yang dianggap baik oleh masyarakat. Begitupun sebaliknya, hasil tradisi budaya yang mempengaruhi kehidupan sosial masyarakat untuk mencapai tujuan yang dipercayainya.

\section{Referensi}

Beng, T.. (1998). Contemporary Vernacular. Singapura: Select Books Pte.

Carmona. (2003). Public Space Urban Space/: The Dimention of Urban Design. London: Architectural Press London.

Gillin, J. (1954). Cultural Sociology: a revision of an introduction to sociology. New York: The Macmillan Company.

Honigmann, J.. (1954). Culture and Personality. New York: Harper \& Brothers.

Koentjaraningrat. (2015). Pengantar Ilmu Antropologi. Jakarta: PT. Rineka Cipta.

Slamet. (2015). Pemanfaatan ruang telaga pada tradisi sedekah bumi desa cerme kidul, kecamatan cerme, kabupaten gresik, 13(1), 47-55.

Soekanto, S. (2015). Sosiologi Suatu Pengantar. Jakarta: Rajawali Pers. 